\title{
Consideration of CSO Floc Characteristics for Modeling the Removal of Solids in a Detention Tank
}

\author{
K.N. Irvine and I.G. Droppo
}

Within the past decade, there has been a renewed interest in urban runoff quality control strategies and technologies. These technologies include wet and dry stormwater detention ponds, constructed wetlands, holding (detention) tanks, vortex/swirl separators, filter basins and filter inlets, grass buffer strips and swales, ultraviolet radiation, porous pavements, and improved street sweeping methods (Tracy and Craig, 1993; Urbonas, 1993; Driscoll and Strecker, 1993; Cheung et al., 1995; Stirrup, 1996; Field et al., 1997; Rochefort et al., 1997; Papa et al., 1997; Sutherland and Jelen, 1997; Kresin et al., 1997; Horsley, 1997; Anderson et al., 1997). The success of many of these technologies will be affected by the characteristics of the sediment transported in the runoff (e.g. particle size, shape, density, composition). In a combined sewer system, the sediment characteristics may vary, depending on factors such as the relative contribution of sanitary flow and stormwater runoff, but generally this sediment moves as flocs (i.e. two or more discrete particles that are joined and transported as a single, larger particle). Lawler (1993) noted that mathematical approaches to describe the kinetics of flocculation were developed as early as 1917. However, Lawler (1993) also indicated that this older work still serves as the foundation for understanding changes in particle size distribution due to flocculation, in part because the complexity of flocculation dynamics has been difficult to capture

Irvine, K. and I. Droppo. 1999. "Consideration of CSO Floc Characteristics for Modeling the Removal of Solids in a Detention Tank." Journal of Water Management Modeling R204-10. doi:

(C) CHI 1999 www.chijournal.org ISSN: 2292-6062 (Formerly in New Applications in Modeling Urban Water Systems. ISBN: 0-9697422-9-0) 
mathematically and because "the ability to measure the size distribution in practice is also difficult...". Some recent modeling efforts have attempted to consider flocculation effects, although most open water and sewer models assume that particles behave as discrete particles (Gailani et al., 1991; Ongley et al., 1992; Bertrand-Krajewski et al., 1993; Coghlin et al., 1993; Wen et al., 1994). The ability to develop satisfactory models of the flocculation process and floc transport dynamics is being facilitated by the increasing sophistication of nondestructive analytical techniques to determine sediment size and settling characteristics (e.g. Lau and Krishnappan, 1992; Kranck et al., 1992; Pisano and Brombach, 1996; Droppo et al., 1997; Marsalek et al., 1998). This type of nondestructive, empirically determined size and settling data also can be valuable in the design and evaluation of stormwater quality control technologies.

The objectives of this study were twofold. First, size (floc and discrete particle) distribution and settling velocity data were summarized for suspended solids collected from a combined sewer system that discharges to Hamilton Harbour, Hamilton, Ontario. Second, these sediment data were used as input to the STORAGE block of PCSWMM4 to assess the sensitivity of the model to variations in sediment characteristics. A standard, hypothetical detention tank was designed and used as input to the STORAGE block for the model evaluations.

\subsection{Methods}

\subsubsection{Kenilworth Sewershed}

Samples of suspended sediment in combined sewer overflows discharging from the Kenilworth Sewershed in Hamilton, Ontario, were collected through the summer of 1996 and in the winter of 1998. A detailed description of the sewershed was provided by Irvine et al. (1998), but in short, the sewershed has a contributing area of 265.5 ha that is serviced principally by a combined sewer system (Figure 1). Much of the land use in the upper part of the sewershed is older, single family residential, with commercial ribbons along major streets (e.g. Kenilworth, Barton, Main). The lower sewershed (approximately $9 \%$ of the total contributing area) is dominated by a mix of industry, including steel mills, railcar manufacture, metal fabrication, construction material recycling, and lead recycling facilities. Paul Theil and Beak Consultants (1991) indicated that much of Hamilton below the Niagara Escarpment discharges a limited quantity of sewage to the sanitary interceptor and based on measurements in the adjacent Strathearne Sewershed (Figure 10.1), determined a typical dry-weather flow rate to be 1.38 $1 \mathrm{~s}^{-1}$ per impervious hectare. 


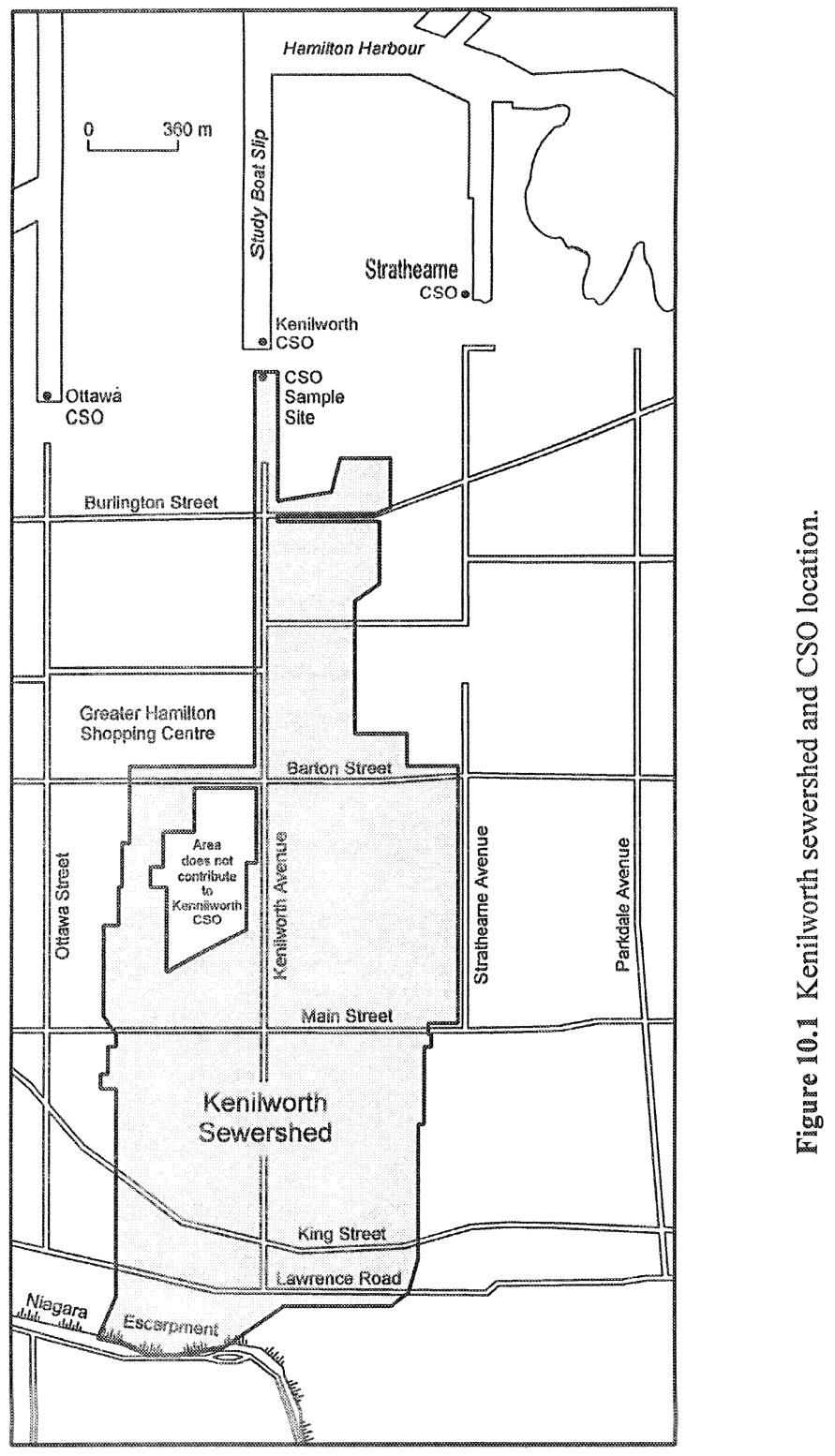




\subsubsection{Sample Collection}

All samples were collected at a manhole approximately $110 \mathrm{~m}$ south (up-stream) of the combined sewer outfall mouth. The sewer is a twinbox at this site, with each side being $2.13 \times 1.75 \mathrm{~m}$. Sampling was done in the eastern box of the twinbox sewer and it was assumed that both sides (eastern and western) were equally mixed. A total of 19 grab samples were collected over nine combined sewer overflow (CSO) events in 1996 (Table 10.1). To the extent possible, samples were collected at evenly-spaced time intervals through an event, although for some of the shorter events only a single sample could be collected. Sampling was done at a point mid-width of the sewer and approximately half the total flow depth below the water surface using a telescoping sample pole fitted with a clean $500 \mathrm{ml}$

Table 10.1 Median $\left(d_{50}\right)$ values $(\mu \mathrm{m})$ by number and volume for the effective and absolute size distributions, 1996 CSO samples.

\begin{tabular}{|c|c|c|c|c|c|}
\hline \multirow[t]{2}{*}{ Date } & \multirow[t]{2}{*}{ Time } & \multicolumn{2}{|c|}{$\mathrm{d}_{50}$ by Number } & \multicolumn{2}{|c|}{$\mathrm{d}_{50}$ by Volume } \\
\hline & & Effective & Absolute & Effective & Absolute \\
\hline April 30 & $9: 15$ & 4.06 & 3.01 & 12.0 & 7.06 \\
\hline May 10 & $15: 40$ & 5.20 & 2.96 & 84.4 & 10.6 \\
\hline June 10 & $11: 20$ & 3.89 & 2.99 & 12.3 & 10.4 \\
\hline June 18 & $9: 30$ & 3.99 & 3.38 & 63.4 & 7.83 \\
\hline June 18 & $10: 20$ & 4.64 & 3.21 & 142 & 13.1 \\
\hline June 18 & $11: 55$ & 4.16 & 2.94 & 15.3 & 9.35 \\
\hline June 18 & $14: 30$ & 4.04 & 2.88 & 14.8 & 7.59 \\
\hline June 24 & $9: 10$ & 4.23 & 3.45 & 16.9 & 7.12 \\
\hline June 24 & $10: 50$ & 4.78 & 3.15 & 12.3 & 5.62 \\
\hline June 24 & $13: 25$ & 4.16 & 2.99 & 10.3 & 5.74 \\
\hline July 2 & $15: 45$ & 4.98 & 3.64 & 45.6 & 12.1 \\
\hline July 2 & $16: 10$ & 4.74 & 3.42 & 36.2 & 8.31 \\
\hline July 15 & $9: 10$ & 4.36 & 3.10 & 27.2 & 15.0 \\
\hline July 15 & $10: 05$ & 4.00 & 3.52 & 17.0 & 16.9 \\
\hline July 15 & $10: 30$ & 4.37 & 3.57 & 14.0 & 17.0 \\
\hline July 24 & $13: 55$ & 4.52 & 4.02 & 353 & 16.5 \\
\hline July 24 & $14: 20$ & 5.19 & 3.53 & 28.3 & 14.7 \\
\hline July 24 & $14: 30$ & 3.96 & 3.66 & 47.2 & 15.6 \\
\hline August 16 & -- & 4.29 & 3.82 & 16.7 & 16.3 \\
\hline Mean & & 4.40 & 3.33 & 51.0 & 11.4 \\
\hline S.D. & & 0.40 & 0.32 & 78.0 & 3.98 \\
\hline $\begin{array}{l}\text { Ratio of Effective } \\
\text { to Absolute ds }\end{array}$ & & 1.32 & & 4.47 & \\
\hline
\end{tabular}


polyethylene bottle. Upon retrieval of the sample, the bottle was gently rotated to ensure that the sediment was evenly mixed and then a 1-3 $\mathrm{ml}$ subsample was poured into an inverted microscope slide for image analysis (Figure 10.2). Monahan (1997) found that pouring a sample from the bottle did not significantly change the floc size distribution, as compared to sampling directly into a microscope settling column from the flow, as typically is done for river studies.

Two flow-proportioned composite samples were collected at the same site in January, 1998, using a Sigma Streamline 900 Series flow meter and pump sampler. These samples were analyzed for both particle size characteristics and settling velocity.

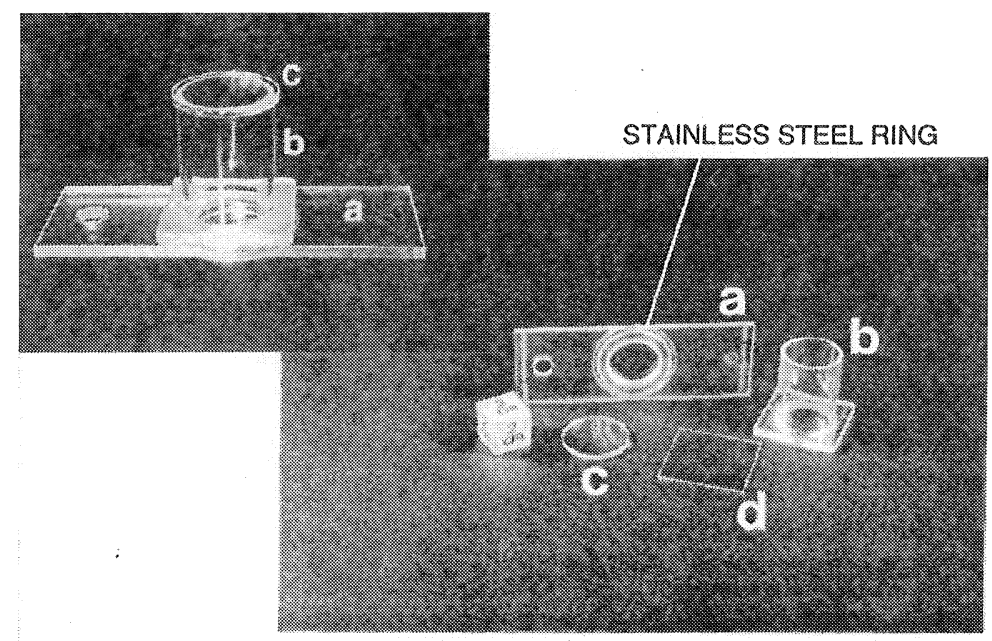

Figure 10.2 Settling system for inverted microscope: (a) $3 \mathrm{ml}$ reservoir; (b) settling column (not required in this study, but typically used for river sampling); (c) top cap to cover settling column; (d) square glass plate to cover $3 \mathrm{ml}$ reservoir (in the absence of the settling column).

\subsubsection{Laboratory Analysis}

The size analysis for the samples collected in 1996 was done at the Image Analysis Laboratory of the National Water Research Institute, Burlington, Ontario, using an Optomax V image analysis system that was connected to a Zeiss Auxiovert 100 inverted microscope and an IBM computer. The samples in the inverted microscope slides were viewed at 100 times magnification, using at least four different fields of view, which resulted in the imaging of between 1,000 and 5,000 particles per sample. The results of this analysis hereafter are referred to 
as the "effective" (i.e. flocculated) size distribution. All samples were refrigerated prior to analysis and the analysis for the effective size distribution typically was done within one week of sample collection. Monahan (1997) found that refrigerated samples could be held up to 21 days without significant change to the size distribution. Samples analyzed for effective size distribution subsequently were sonicated and then re-imaged to determine the primary particle size distribution (hereafter referred to as the "absolute" size distribution). The sonicated samples were allowed to settle for a minimum of four hours before imaging was done.

The size distribution characteristics for the 1998 samples were determined using Northern Exposure Image Analysis software (distributed by Empix Imaging) installed on a Pentium personal computer and connected to the Zeiss Auxiovert 100 inverted microscope. The Optomax V and Northern Exposure systems provide similar results, but the Northern Exposure software has greater flexibility in reproducing and manipulating digital images. Settling velocity for the 1998 samples was measured following the method described by Droppo et al. (1997). Briefly, drops of the combined sewage sample were introduced into the top of a 2.5 litre settling column, using a pipette with a $3.74 \mathrm{~mm}$ bore. As the sediment passed through the field of view of a Nikon SMZ-2T stereoscopic microscope, it was videotaped on a super VHS VCR connected to a CCD camera (Figure 10.3). The settling velocity of each particle was then derived using the Northern Exposure software, in which two video frames a known time interval apart were digitally overlapped. The distance between the particle images was measured, as was the size of the particle.

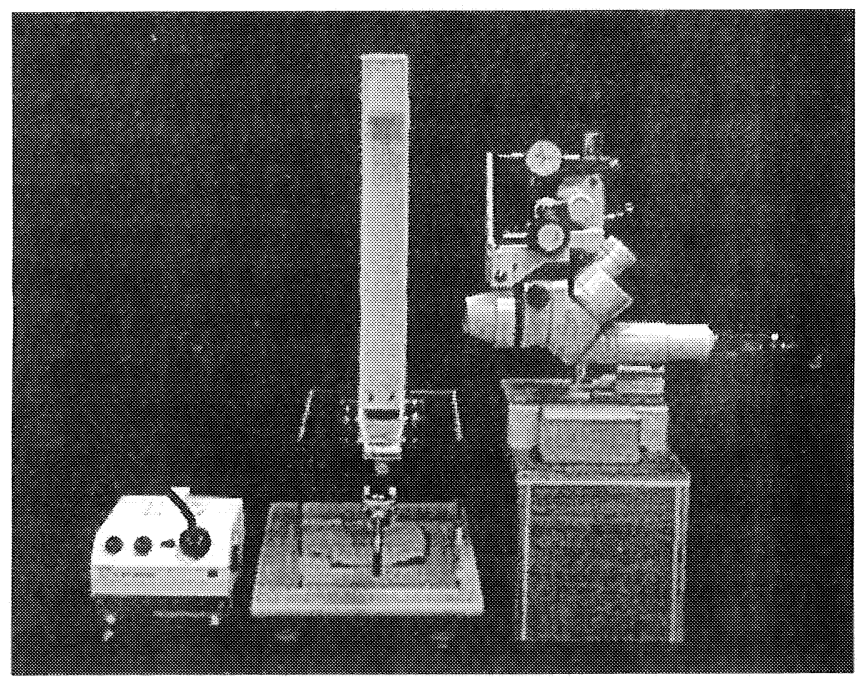

Figure 10.3 System to determine settling velocity. Middle is the 2.5 litre settling column. Right is the Nikon SMZ-2T stereoscopic microscope with CCD camera. 


\subsubsection{PCSWMM4 Modeling}

The RUNOFF and TRANSPORT blocks of PCSWMM4 (distributed by CHI, Guelph, Ontario) were used to simulate surface runoff and route the runoff through the sewer network. Details of the model construction are provided by Irvine et al. (1998). The simulated overflow that would discharge to the harbour from the sewershed subsequently was entered into the STORAGE block, where it was treated using a hypothetical rectangular detention tank having a travel length of $90 \mathrm{~m}$ and a width of $45 \mathrm{~m}$. These dimensions represent a length-to-width ratio of two, which is the same as that used by Nix et al. (1988) in their theoretical evaluation of suspended solids removal in a detention basin. The maximum depth of the tank was set at three meters, thereby providing a detention capacity of $12,150 \mathrm{~m}^{3}$. This tank capacity is smaller than some detention tanks that have been or are being constructed by the Hamilton-Wentworth Region, under its Pollution Control Plan (PCP) (Paul Theil Associates and Beak Consultants, 1991). For example, Stirrup (1996) noted the Waterfront Park CSO tank, completed in 1993 at a cost of approximately $\$ 9.3$ million, has a total capacity of approximately $20,000 \mathrm{~m}^{3}$ and the Catherine/Ferguson CSO tank was under construction for a cost of approximately $\$ 9.1$ million with a capacity of approximately $25,000 \mathrm{~m}^{3}$. The much larger Main/King CSO tank has a capacity of approximately 75,000 $\mathrm{m}^{3}$ (at an estimated cost of $\$ 23$ million), while the James Street CSO tank and inline storage has a capacity of $3,200 \mathrm{~m}^{3}$ (and a construction cost of $\$ 1.5$ million).

For most simulation runs it was assumed that treated outflow from the tank would discharge to the harbour through a bottom orifice at a constant rate of 0.78 $\mathrm{m}^{3} \mathrm{~s}^{-1}$. In this sense, we are considering the tank as a flow-through system with temporary retention capacity. As noted by Nix et al. (1988), this withdrawal configuration may not be optimal for sediment treatment, but for the purposes of comparing settling characteristics, this is not a critical consideration. Simulation of solids deposition within a detention unit can be accomplished using different approaches within the STORAGE block. The solids can be characterized using a concentration approach in which the removal rate is proportional to the concentration present in the unit (i.e. a first order reaction) (Huber and Dickinson, 1988). Alternatively, the solids can be characterized and removed using either: (i) a combination of particle size and specific gravity; or (ii) a settling velocity distribution. We used the latter two options ((i) and (ii)) in this study and as such the STORAGE block assumes a plug flow approach to estimate solids removal. Details of the removal computations are provided by Huber and Dickinson (1988). The particle size distribution used for our simulations was measured directly with the Northern Exposure system, while the specific gravity (also referred to as the wet density of the floc or particle density) was calculated using the settling velocity data and solving the Stokes equation as discussed by Droppo et al., 1997: 


$$
\mathrm{vs}=\frac{1}{18} D^{2}\left(\rho_{\mathrm{r}}-\rho_{\mathrm{w}}\right) \frac{\mathrm{g}}{\mu}
$$

where:

$$
\begin{aligned}
\mathrm{vs} & =\text { settling velocity, } \\
\mathrm{D} & =\text { particle diameter, } \\
\rho_{\mathrm{f}} & =\text { the wet density of the floc, } \\
\rho_{\mathrm{w}} & =\text { the density of water, } \\
\mathrm{g} & =\text { acceleration due to gravity, and } \\
\mu & =\text { the dynamic viscosity of water. }
\end{aligned}
$$

Settling velocity for different particle sizes was measured using the procedure described in the previous section for particles with a minimum size of $90 \mu \mathrm{m}$ or greater (the minimum resolution of the system). Settling velocity for particles smaller than $90 \mu \mathrm{m}$ was estimated by extrapolating the regression between the measured settling velocities and particle sizes.

The particle removal simulations were done using the rainfall from a storm observed on July 15, 1996. Rainfall data collected at the Mount Hope airport ( $10.5 \mathrm{~km}$ southwest of the site) indicated that the storm had a duration of 10 hours and produced $37.6 \mathrm{~mm}$ of rain. Peak rainfall intensity for this storm was $9.4 \mathrm{~mm}$ $\mathrm{hr}^{-1}$. For comparative purposes, Paul Theil Associates and Beak Consultants (1991) indicated that in a typical rainfall year Hamilton would experience five storm events with a total depth greater than $30 \mathrm{~mm}$ and a two hour, $35 \mathrm{~mm}$ storm would occur, on average, once per year. To simplify interpretation of modeled settling rates in response to changes in the sediment characteristics, a constant suspended sediment concentration of $193 \mathrm{mg} \mathrm{l}^{-1}$ was assumed to enter the theoretical detention tank during the storm. This concentration was the mean value of the nineteen samples collected in 1996.

\subsection{Results}

\subsubsection{Size Characteristics of CSO Samples}

A visual inspection indicated that the CSO samples were highly flocculated (Figure 10.4). The effective and absolute size distributions of a sample can be expressed either as a percent by number (of particles) or a percent by volume and typical size distribution results for each method of expression are shown in Figure 10.5. The percent by volume and number in all cases were standardized to an equivalent spherical diameter, as discussed by Droppo and Ongley (1992). The pattern of the distributions expressed by volume and number were similar to those 


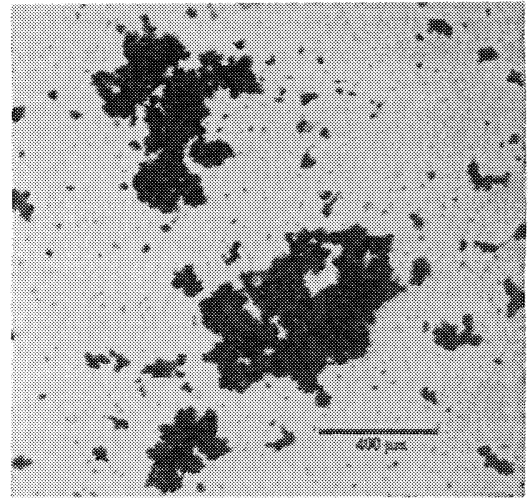

(a)

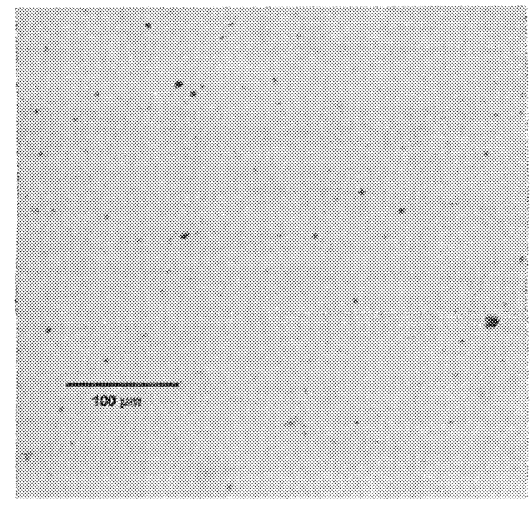

(b)

Figure 10.4 (a) flocculated sediment from January 8, 1998 CSO sample;

(b) same CSO sample after sonication.

observed in various natural and engineered environments (e.g. Irvine et al., 1995; Droppo et al., 1996; 1997; Monahan, 1997). The distribution pattern indicates that a relatively small number of flocs comprised the majority of the sample volume, while conversely, a great number of sediment particles had a relatively small volume.

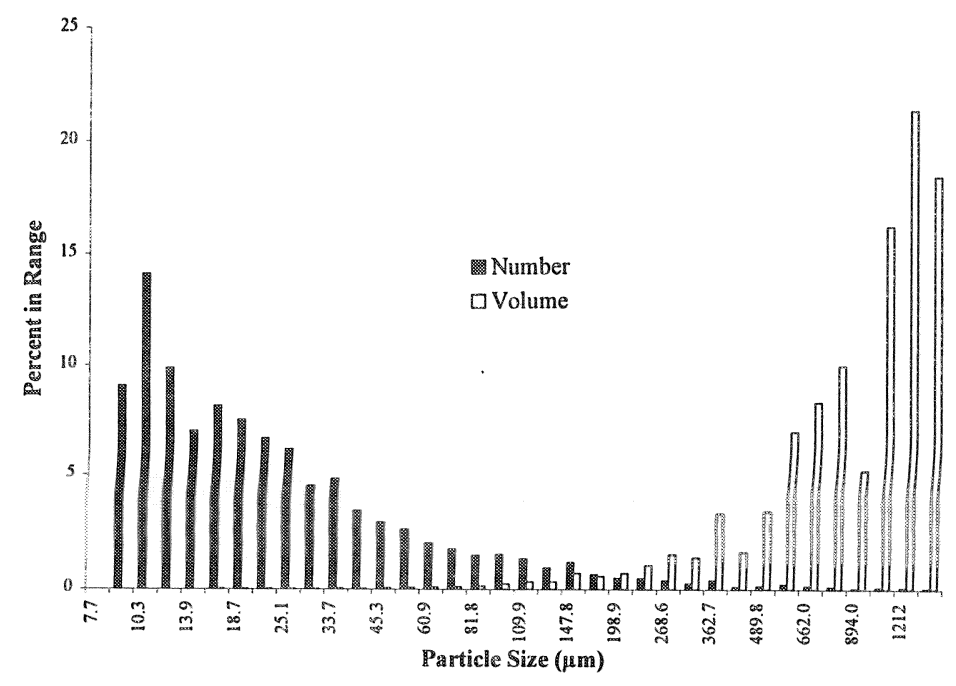

Figure 10.5 Relative frequency distribution for effective (flocculated) size, percent by volume and by percent by number, January 8,1998 CSO sample. 
The difference in the effective and absolute size distributions is summarized in Table 10.1 using the median $\left(\mathrm{d}_{50}\right)$ of each distribution. Typical effective and absolute size distributions (percent by volume) are shown in Figure 10.6. The absolute size distribution shows a characteristic shift to the left (or fining trend) because the flocculated particles were mechanically broken (sonicated) into their primary particles of composition. The ratios of the mean $\mathrm{d}_{50}$ values for the effective and absolute size distributions were consistent with the results shown in Figures 10.5 and 10.6 , as the $d_{50}$ for the absolute distributions typically were smaller than the $d_{50}$ for the flocculated material.

The BestFit software, an Excel spreadsheet add-in (Palisade Corporation, 1996), was used to identify the distribution(s) that most likely produced the effective and absolute size data, by volume and by number. BestFit compared the sample data with 25 theoretical probability distributions, using a maximumlikelihood estimator approach. Subsequently, Chi-square and KolmogorovSmirnov test statistics were calculated to evaluate goodness-of-fit and BestFit ranked the fit of each distribution based on the test statistic results. Results of this probability distribution fitting effort are summarized in Table 10.2, for the 19 samples from 1996. The rankings of the most appropriate distributions may differ for the two test statistics because of different emphasis in the calculation of the statistics (Palisade Corporation, 1996). The results in Table 10.2 were developed by considering the frequency of the top three relative rankings from both tests for each of the 19 samples.

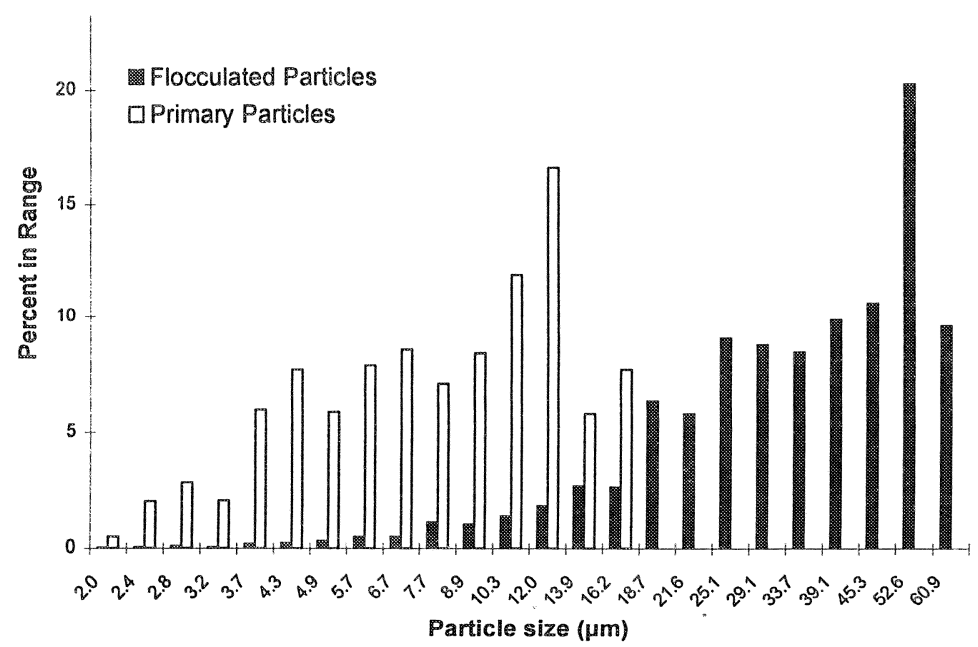

Figure 10.6 Effective and absolute size distributions, percent by volume, CSO sample 12. 
Table 10.2 Best fitting theoretical distributions for 1996 sewer samples, as ranked using Bestfit (Palisade Corporation, 1996).

\begin{tabular}{llll}
\hline $\begin{array}{l}\text { \% by Volume, } \\
\text { Effective Size } \\
\text { Distribution }\end{array}$ & $\begin{array}{l}\text { \% by Number, } \\
\text { Effective Size }\end{array}$ & $\begin{array}{l}\text { \% by Volume, } \\
\text { Absolute Size } \\
\text { Distribution }\end{array}$ & $\begin{array}{l}\text { \% by Number, } \\
\text { Absolute Size } \\
\text { Distribution }\end{array}$ \\
\hline Beta & Pearson V & Beta & Pareto \\
Weibull & Pearson VI & Uniform & Pearson V \\
Rayleigh & Log-normal & Rayleigh & Beta \\
\hline
\end{tabular}

\subsubsection{Settling Velocity Characteristics}

Simple linear regression was conducted between settling velocity and effective (flocculated) size of the particles and the results are shown in Figure 10.7. There was considerable scatter in the data, as indicated by the low $\mathrm{R}^{2}$ values (35-59\%), but the slopes of the regressions were significantly different from $0(a=0.05)$ and the regression equations for each of the two samples were remarkably similar. Possible sources of the scatter in the data are discussed below.

\subsubsection{PCSWMM4 STORAGE Block Results}

A total of 13 model runs using different input characteristics was done to evaluate the sensitivity of the STORAGE block to size/density characteristics of the particles, settling velocity distribution, and hydraulics of the detention tank. The characteristics of the different runs are summarized in Table 10.3. Up to 10 particle size classes and specific gravities or up to 10 settling velocity classes can be input, as indicated in Table 10.3. The particle characteristics for the January 8,1998 sample were used as the basis of the simulation inputs.

The modeled inflow volume to the tank for the storm of July 15, 1996 was $26,047 \mathrm{~m}^{3}$ and the peak inflow rate was $2.34 \mathrm{~m}^{3} \mathrm{~s}^{-1}$. The estimated total sediment load (volume of flow $\mathrm{x}$ concentration of suspended sediment) entering the detention tank for this storm was $5,027 \mathrm{~kg}$. Except for some minor evaporation loss, all flow entering the detention tank in runs 1 through 12 ultimately would discharge to the harbour because we have assumed a constant "treated" outflow rate of $0.78 \mathrm{~m}^{3} \mathrm{~s}^{-1}$. The sediment load leaving the detention tank in runs 1 through 12 averaged around $1,224 \mathrm{~kg}$, which represents a removal efficiency of $75.7 \%$. The variation in retention efficiency for these runs was less than $1 \%$, indicating that the model, as constructed, was not sensitive to variations in suspended sediment characteristics.

In the final run, the hydraulics of the detention tank were changed so that the treated outflow to the harbour would not begin to discharge until the depth of water in the tank was at least two meters. After that depth, the outflow discharge was governed by the equation: 
Table 10.3 Summary of inputs used for Storage Block runs.

\begin{tabular}{|c|c|}
\hline $\begin{array}{c}\text { Run } \\
\text { \# }\end{array}$ & Input Summary \\
\hline 1 & $\begin{array}{l}10 \text { particle size classes }(\mu \mathrm{m}) \text { and specific gravities used: } 7.2-11.1(2.45)^{*} ; 11.2-15.0(2.43) \\
15.1-20.1(2.40) ; 20.2-27.0(2.33) ; 27.1-42.1(2.20) ; 42.2-65.6(1.86) ; 65.7-118.4(1.40) \\
118.5-249.2(1.15) ; 249.3-528.0(1.05) ; 528.1-1121(1.02) \\
\text { Proportion of distribution for respective size classes: } 0.33 ; 0.15 ; 0.14 ; 0.11 ; 0.11 ; 0.06 \\
0.05 ; 0.03 ; 0.01 ; 0.005\end{array}$ \\
\hline 2 & $\begin{array}{l}5 \text { particle size classes }(\mu \mathrm{m}) \text { and specific gravities used: } 7.2-11.1(2.45)^{*} ; 11.2-27.0(2.40) \\
27.1-65.6(2.00) ; 65.7-249.2(1.28) ; 249.3-1121(1.04) \\
\text { Proportion of distribution for respective size classes: } 0.33 ; 0.40 ; 0.17 ; 0.08 ; 0.02\end{array}$ \\
\hline 3 & $\begin{array}{l}3 \text { particle size classes }(\mu \mathrm{m}) \text { and specific gravities used: } 7.2-11.1(2.45)^{*} ; 11.2-65.6(2.2) \\
65.7-1121(1.16) \\
\text { Proportion of distribution for respective size classes: } 0.33 ; 0.57 ; 0.10\end{array}$ \\
\hline 4 & $\begin{array}{l}10 \text { settling velocity }\left(\mathrm{mm} \mathrm{s}^{-1}\right) \text { classes: } 1.66-1.68(0.33)^{* *} ; 1.681-1.70(0.15) ; 1.71-1.72(0.14) \text {; } \\
1.73-1.76(0.11) ; 1.761-1.83(0.11) ; 1.84-1.95(0.06) ; 1.951-2.20(0.05) ; 2.21-2.85(0.03) \\
2.851-4.21(0.01) ; 4.211-7.12(0.005)\end{array}$ \\
\hline 5 & $\begin{array}{l}5 \text { settling velocity }\left(\mathrm{mm} \mathrm{s}^{-1}\right) \text { classes: } 1.66-1.68(0.33)^{* *} ; 1.681-1.76(0.40) ; 1.761-1.95(0.17) \\
1.951-2.85(0.08) ; 2.851-7.12(0.02)\end{array}$ \\
\hline 6 & 3 settling velocity $\left(\mathrm{mm} \mathrm{s}^{-1}\right)$ classes: $1.66-1.68(0.33)^{* *} ; 1.681-1.95(0.57) ; 1.951-7.12(0.10)$ \\
\hline 7 & $\begin{array}{l}10 \text { particle size classes in the same proportion as run } 1 \text {, but specific gravity was set to } 2.65 \\
\text { for all classes }\end{array}$ \\
\hline 8 & $\begin{array}{l}5 \text { particle size classes in the same proportion as run } 2 \text {, but specific gravity was set to } 2.65 \\
\text { for all classes }\end{array}$ \\
\hline 9 & $\begin{array}{l}3 \text { particle size classes in the same proportion as run } 3 \text {, but specific gravity was set to } 2.65 \\
\text { for all classes }\end{array}$ \\
\hline 10 & $\begin{array}{l}10 \text { particle size classes }(\mu \mathrm{m}) \text { and specific gravities used: } 0.45-3.0(2.45)^{*} ; 3.1-11.1(2.45) \text {; } \\
11.2-15.0(2.43) ; 15.1-20.1(2.40) ; 20.2-27.0(2.33) ; 27.1-42.1(2.20) ; 42.2-65.6(1.86) ; 65.7- \\
118.4(1.40) ; 118.5-249.2(1.15) ; 249.3-1121(1.05) \\
\text { Proportion of distribution for respective size classes: } 0.3 ; 0.03 ; 0.15 ; 0.14 ; 0.11 ; 0.11 ; 0.06 \text {; } \\
0.05 ; 0.03 ; 0.02 \\
\text { Principal difference between run } 1 \text { and } 9 \text { is that } 30 \% \text { of the size distribution was placed in } \\
\text { the clay size range }\end{array}$ \\
\hline 11 & $\begin{array}{l}10 \text { particle size classes and specific gravities, similar to run } 1 \text {. The principal difference } \\
\text { between run } 1 \text { and } 11 \text { is that } 94 \% \text { of the sample was placed in the } 230-1200 \mu \mathrm{m} \text { range }\end{array}$ \\
\hline 12 & $\begin{array}{l}3 \text { particle size classes and specific gravities, similar to run } 3 \text {. The principal difference } \\
\text { between run } 3 \text { and run } 12 \text { is that } 99.5 \% \text { of the sample was }>65.7 \mu \mathrm{m}\end{array}$ \\
\hline 13 & $\begin{array}{l}\text { Size classes and specific gravities identical to run } 10 \text {, but hydraulics of detention tank } \\
\text { changed to increase holding time of water }\end{array}$ \\
\hline
\end{tabular}

specific gravity for the particular size class is shown in the bracket
proportion of particles in this settling velocity class 

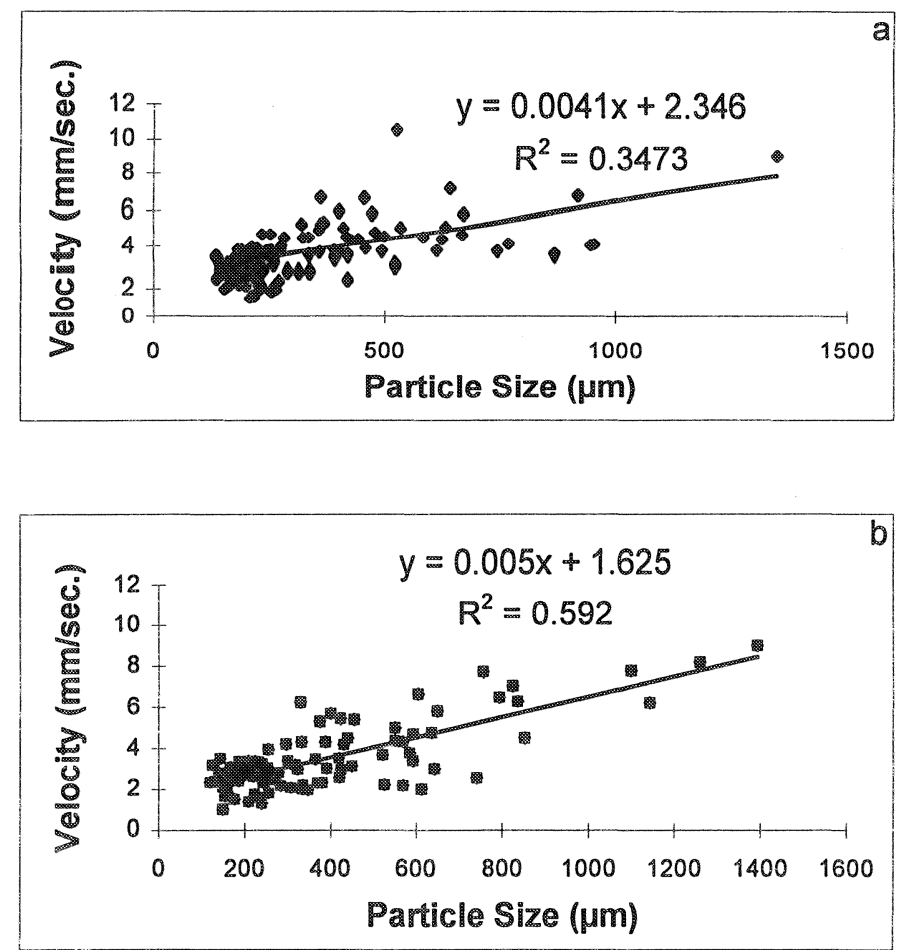

Figure 10.7 Regression results for settling velocity against effective particle size, (a) January 6, 1998 CSO sample; (b) January 8, 1998 CSO sample.

$$
\mathrm{Q}=\mathrm{CA}(2 \mathrm{gH})^{0.5}
$$

where:

$$
\begin{aligned}
Q= & \text { the discharge from the orifice } \\
\mathrm{C}= & \text { the orifice coefficient (taken as } 0.7) \\
\mathrm{A}= & \text { the cross-sectional area of the orifice, } \\
\mathrm{g}= & \text { acceleration due to gravity, and } \\
\mathrm{H}= & \text { the head from the center of the orifice to the water } \\
& \text { surface. }
\end{aligned}
$$

The total volume of treated outflow to the harbour for this run was estimated to be $19,957 \mathrm{~m}^{3}$, or $77 \%$ of the inflow volume. The remaining $23 \%$ of the inflow would be returned to the interceptor without impacting the harbour. Because of the additional holding/settling time for this run, as compared to runs 1 through 12 , the tank retained essentially $100 \%$ of the incoming sediment. 


\subsection{Discussion}

The observed and fitted theoretical distributions for percent by number and percent by volume, samples 8 and 15 (1996 effective size data), are shown in Figure 10.8. The percent by volume data showed greater variability with respect to the best fit theoretical distribution, although in general it appeared that the Beta distribution was most appropriate. The Pearson Type V distribution generally appeared most appropriate for the percent by number distributions and the Pearson distribution has the advantage of being commonly used in hydrologic studies. In reviewing street dust size distribution data published in various studies, Klemetson (1985) concluded that a log-normal distribution provided an appropriate fit. It is likely that due to hydraulic sorting and flocculation mechanisms, the size distribution of the sediment changes during movement from the surface, mixing with sanitary sewage, and transport through the sewer system. Factors affecting size distribution change (including flocculation) and the dynamics of the changes should be evaluated more rigorously for inclusion in a sewer modeling framework.

Some recent literature (e.g. Aiguier et al., 1996; Lucas-Aiguier et al., 1998; Pisano and Brombach, 1996; Hedges et al., 1998) has emphasized the importance of knowing settling velocity profiles of CSO sediment (as opposed simply to size distribution) in designing effective detention basins. For example, Hedges et al. (1998) determined nutrient and metals levels and loadings for different settling velocity classes in primarily dry weather flow samples. They concluded that any sedimentation device capable of removing solids with a settling velocity greater than $0.18 \mathrm{~mm} \mathrm{~s}^{-1}$ could remove 50 to $60 \%$ of COD, TKN, and P, but between 70 and $90 \%$ of most metals (e.g. $\mathrm{Zn}, \mathrm{Hg}, \mathrm{Cu}$ ).

The median settling velocities $\left(\mathrm{vs}_{50}\right)$ for our samples were $3.65 \mathrm{~mm} \mathrm{~s}^{-1}$ and $3.01 \mathrm{~mm} \mathrm{~s}^{-1}$ for the January 6 and January 8,1998 samples, respectively. Pisano and Brombach (1996) summarized settling velocity characteristics from studies done in North America and Europe and found that the $\mathrm{vs}_{50}$ for CSO samples from North America ranged between 0.1 and $54.5 \mathrm{~mm} \mathrm{~s}^{-1}$ (geometric mean of $2.17 \mathrm{~mm}$ $\left.\mathrm{s}^{-1}\right)$. The $\mathrm{vs}_{50}$ for CSO samples from a major study done in Germany ranged between 1.2 and $14 \mathrm{~mm} \mathrm{~s}^{-1}$ (geometric mean of $4.2 \mathrm{~mm} \mathrm{~s}^{-1}$ ). Aiguier et al. (1996) presented the $\mathrm{vs}_{50}$ for studies done in France, the UK, and Germany, these being $0.9-3.0 \mathrm{~mm} \mathrm{~s}^{-1} ; 1.3 \mathrm{~mm} \mathrm{~s}^{-1}$; and $1.5-8.9 \mathrm{~mm} \mathrm{~s}^{-1}$, respectively. Our vs ${ }_{50}$ values fell within the general range reported in the literature and there was little difference in the $\mathrm{vs}_{50}$ between our two samples.

Lucas-Aiguier et al. (1998) noted that variability in the $\mathrm{vs}_{50}$ depends on the variability of the sewer samples themselves, as well as the method of sampling and analysis. Our samples represented only suspended material and this would exclude heavier, grit material that may have settling velocities in the range of 10 to $150 \mathrm{~mm} \mathrm{~s}^{-1}$ (Pisano and Brombach, 1996). We have assumed that this heavier 

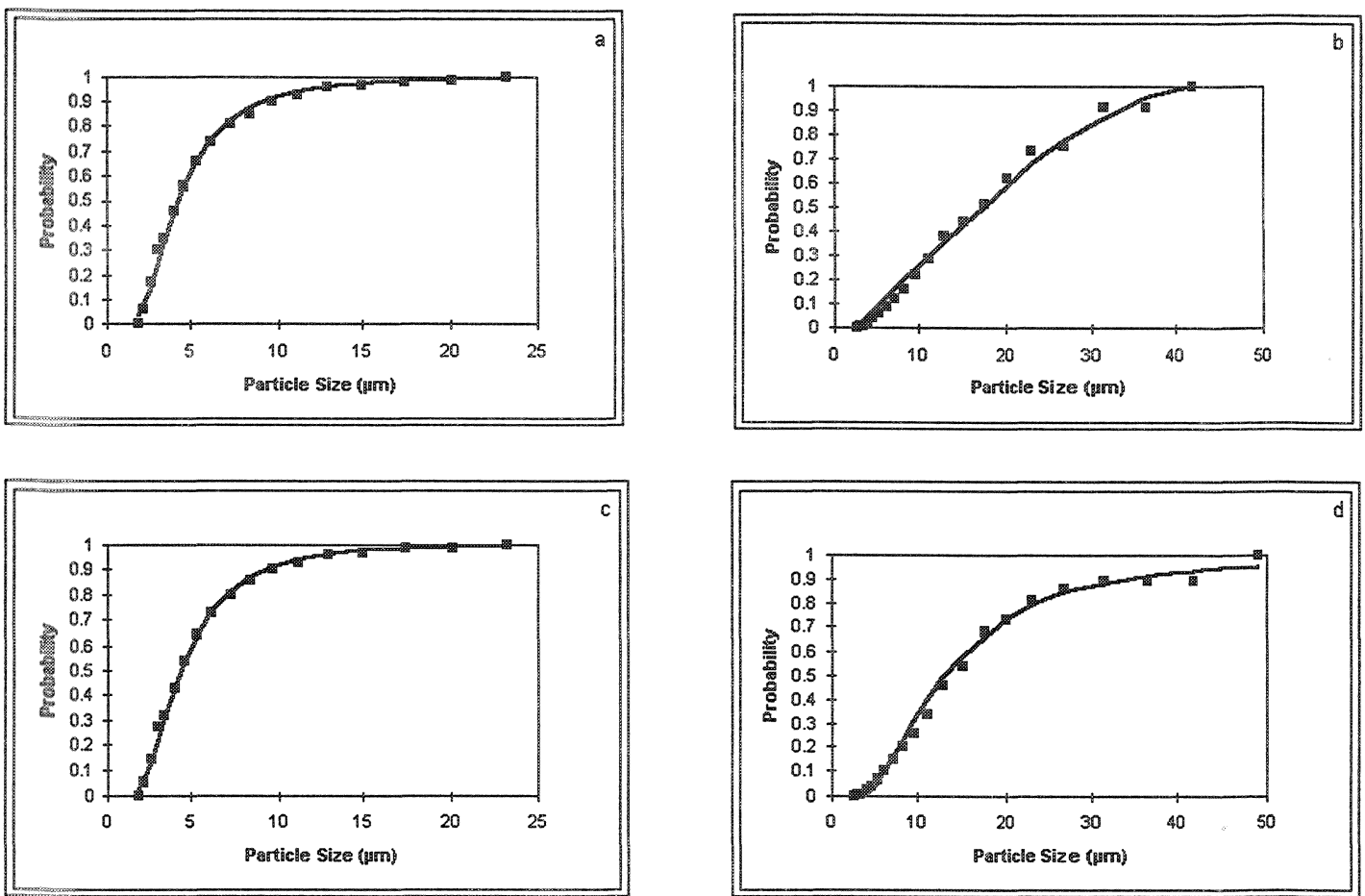

Figure 10.8 Observed (squares) and theoretical probability (line) for: (a) percent by number, sample 8 (fit with a Pearson V distribution); (b) percent by volume, sample \& (iit with a B eta distribution); (c) percent by number, sample 15 (fit with a Pearson V distribution); and (d) percent by volume, sample 15 (fit with a Pearson V distribution). 
material would have a smaller environmental impact (e.g. due to lower contaminant level association, see Forstner and Wittmann, 1983 or Allen, 1986) and therefore have focused on the suspended material. Lucas-Aiguier et al. (1998) indicated that settling velocity measurements done in Germany using the UFT method generally represent the settleable solids fraction (i.e. the sample is allowed to settle in an Imhoff cone for 2 hours prior to analysis). The settling velocities of these solids tend to be $>0.1 \mathrm{~mm} \mathrm{~s}^{-1}$ and therefore these data typically have higher $v_{50}$. Lucas-Aiguier et al. (1998) also evaluated four commonly used methods to determine settling velocity and there was some variation in pretreatment, settling column size, depth of sample withdrawal, and the nature of column water into which the sample was introduced. It was concluded that there is a need to standardize analytical methodologies. Our method differs from those reviewed by Lucas-Aiguier et al. (1998) in that an optical approach was employed. Although our $\mathrm{vs}_{50}$ were within the range of those reported in the literature, it would be useful to include the optical method in round-robin comparisons.

Settling velocity was significantly related to the effective size of the particles, as indicated in Figure 10.7. However, there was considerable scatter in the data which may be related to factors such as floc shape and density. Klemetson (1985) presented equations to calculate the drag coefficient for particles of different shapes and these equations illustrate the interaction between shape, density, and settling velocity:

$$
\begin{gathered}
\mathrm{C}_{D}=\frac{24}{\mathrm{NR}}+\frac{5}{\sqrt{\mathrm{NR}}}+0.26 \quad \text { for spherical particles; } \\
\mathrm{CD}_{\mathrm{D}}=\frac{24}{\mathrm{NR}}+\frac{5}{\sqrt{\mathrm{NR}}}+1.14 \quad \text { for disk-shaped particles; } \\
\mathrm{CD}_{\mathrm{D}}=\frac{10}{(\mathrm{NR})^{0.289}}+\frac{2}{\sqrt{\mathrm{NR}}}+1.14 \quad \text { for cylinder-shaped particles; }
\end{gathered}
$$

where:

and

$$
\begin{aligned}
C_{D}= & \text { the drag coefficient; } \\
N_{R}= & \text { Reynolds Number: } \\
& \quad N R=\frac{\text { vs } \bullet D \bullet \rho}{\mu} \\
\text { vs }= & \text { settling velocity, } \\
D= & \text { particle diameter, } \\
\rho= & \text { particle density, and } \\
\mu= & \text { the dynamic viscosity of the fluid. }
\end{aligned}
$$


Figure 10.9 summarizes the relationships between particle porosity, excess density, and size. The excess density simply is the particle density (calculated by Equation 10.1) minus 1 (for the density of water). Clearly, the smaller and less flocculated particles have a higher density, while the larger, flocculated particles have greater porosity.

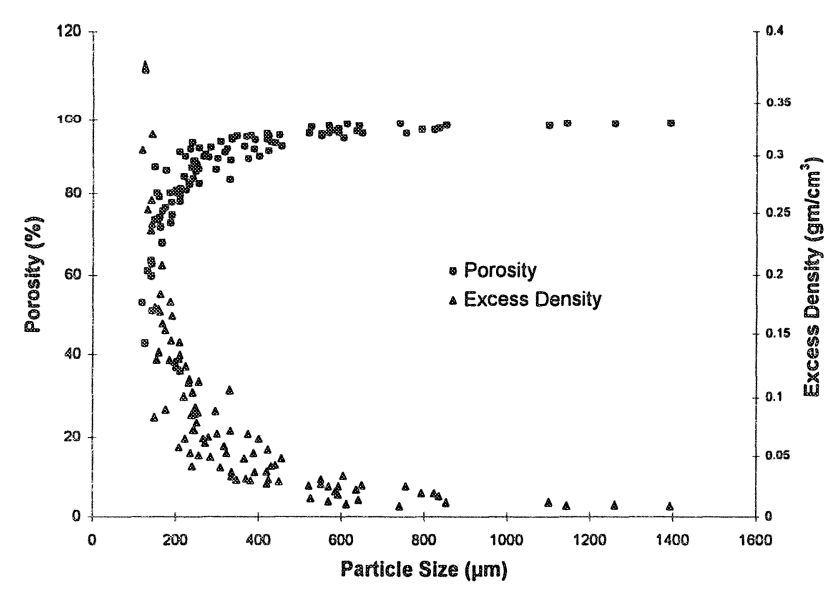

Figure 10.9 Relationship between effective particle size, floc porosity, and excess density, January 8, 1998 CSO sample.

Sediment transport studies often rely on the classical Stokes Law (e.g. Equation 10.1) to evaluate transport/deposition dynamics for the particular system (e.g. Hemond and Fechner, 1994; McCuen, 1998). Stokes Law originally was developed for solid, spherical, quartz particles, having a density of 2.65 , and settling under quiescent conditions. As indicated in Figure 10.9, CSO flocs have a much lower density than quartz particles, thereby influencing settling velocity. If we simplistically assume that the flocs settled as solid, spherical, particles at a density of 2.65 , the relationship between settling velocity and size for our samples could be represented as in Figure 10.10. Also shown in Figure 10.10 is the regression line for our measured settling velocity-size data. Clearly, Stokes Law over-predicts settling velocity, particularly for the larger particle sizes $(>300 \mu \mathrm{m})$, thereby suggesting that removal efficiency of detention tanks also could be overpredicted if an unmodified Stokes Law was used in settling calculations. Since the original development of Stokes Law, modifications have been proposed and in fact the STORAGE block of PCSWMM4 applies one of these modifications:

$$
\mathrm{vs}=\sqrt{\frac{4}{3} \frac{\mathrm{gD}}{\mathrm{CD}_{\mathrm{D}}}\left(\mathrm{S}_{\mathrm{p}}-1\right)}
$$




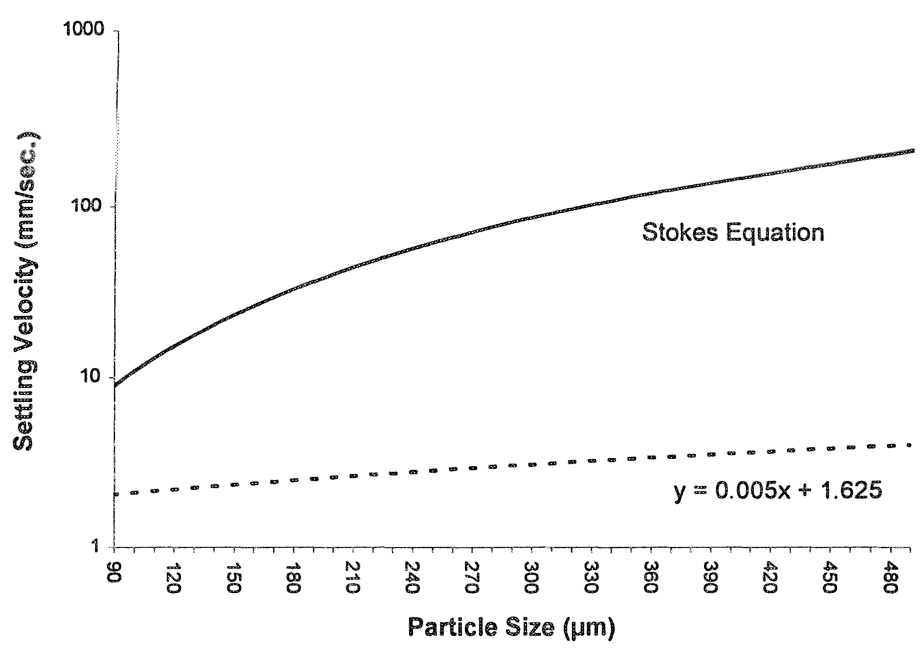

Figure 10.10 Stokes Law of settling (see Equation 10.1) for a range of particle sizes and our regression results for the January 8, 1998 CSO sample.

where $S_{p}$ is specific gravity (dimensionless) and the drag coefficient is calculated using variations of Equation 10.3 (see Huber and Dickinson, 1988). Equation 10.7 is used when the size and density input option is selected for the PCSWMM4 runs. Although the STORAGE block has the flexibility of considering either sediment settling velocity directly, or calculating settling velocity based on particle size and density, the results in Table 10.3 indicated that for our test configuration the model was more sensitive to changes in hydraulics of the detention tank (e.g. travel time, holding time) than to variations in the sediment characteristics.

\subsection{Conclusion}

Sediment in combined sewer overflows from the Kenilworth Sewershed, Hamilton, Ontario, were highly flocculated, with a large volume of the sediment being contained within a relatively small number of flocs. The size distribution of the CSO samples was well-fit with a Beta distribution when expressed as a percent by volume and a Pearson $V$ distribution when expressed as a percent by number. There is a need for further research to evaluate the evolution of sediment size distributions from surface washoff, through mixing with sanitary flow, and subsequent transport through the sewer and into a receiving water body. 
The median settling velocities of our samples $\left(3.65 \mathrm{~mm} \mathrm{~s}^{-1}\right.$ and $\left.3.01 \mathrm{~mm} \mathrm{~s}^{-1}\right)$ were within the range of published median settling velocities for combined sewer samples. Settling velocity and/or size distribution and particle density data should be considered in the design of any sedimentation device. Flocculation of sediment can increase settling velocity and remove particle sizes that normally would not settle. Given the data of Hedges et al. (1998), it appears that any sedimentation device capable of removing particles having a settling velocity $>0.18 \mathrm{~mm} \mathrm{~s}^{-1}$ also can be highly efficient in removing metals. This suggests that the sediment from the Kenilworth Sewershed could be treated effectively with a sedimentation device.

The STORA GE block of PCSWMM4 provides good flexibility in accepting either settling velocity or size and particle density data as input to estimate sedimentation rates within a detention tank. However, sedimentation rate estimates were more sensitive to changes in the hydraulics (i.e. hydraulic residence times) of the tank than changes in sediment characteristics. Furthermore, neither SWMM nor our study consider changes in floc size or structure within the tank during the detention period. It would be useful to undertake a more extensive evaluation of the STORA GE block capabilities using real sediment and detention tank data to integrate a more rigorous approach to the settling velocity algorithms.

\section{Acknowledgments}

Christine Jaskot, Kristian Curran, and Shannon Vickers provided outstanding support in the sampling and analytical work for this project.

\section{References}

Allan, R.J. 1986. The Role of Particulate Matter in the Fate of Contaminants in Aquatic Ecosystems. Scientific Series No. 142, Environment Canada, Inland Waters Directorate, Burlington, Ont. 128 p.

Aiguier, E., Chebbo, G., Bertrand-Krajewski, J.L., Hedges, P., and Tyack, N. 1996. Methods for determining the settling velocity profiles of solids in storm sewage. Wat. Sci. Tech., 33(9): 117-125.

Anderson, B.C., Caldwell, R.J., Crowder, A.A., Marsalek, J., and Watt, W.E. 1997. Design and operation of an aerobic biological filter for the treatment of urban stormwater runoff. Water Quality Research Journal of Canada, 32(1):119-139.

Bertrand-Krajewski, J.L., Briat, P., and Scrivener, O. 1993. Sewer sediment production and transport modelling: A literature review. Journal of Hydraulic Research, 31:435460.

Cheung, P., J. Li, D.G. Weatherbe and J. Marsalek. 1995. "Urban Runoff Control Costs at Ontario RAP Sites." Journal of Water Management Modeling R183-07. doi:

10.14796/JWMM.R183-07. 
Coghlan, B.P., Ashley, R.M., and Jefferies, C. 1993. An appraisal of suspended sediment transport modelling methods for an interceptor sewer. Water Science and Technology, 27:81-91.

Driscoll, E.D. and Strecker, E.W. 1993. Assessment of BMPs being used in the US and Canada. In J. Marsalek and H.C. Torno (eds.) Sixth International Conference on Urban Storm Drainage, Niagara Falls, Ontario, Seapoint Publishing, Victoria, B.C. pp. 945-950.

Droppo, I.G. and Ongley, E.D. 1992. The state of suspended sediment in the freshwater fluvial environment: A method of analysis. Water Research, 26(1):65-72.

Droppo, I.G., Flannigan, D.T., Leppard, G.G., Jaskot, C., and Liss, S.N. 1996. Floc stabilization for multiple microscopic techniques. Applied and Environmental Microbiology, 62(9):3508-3515.

Droppo, I.G., Leppard, G.G., Flannigan, D.T., and Liss, S.N. 1997. The freshwater floc: A functional relationship of water and organic and inorganic floc constituents affecting suspended sediment properties. Water, Air and Soil Pollution, 99:43-54.

Field, R., Averill, D., O'Connor, T.P., and Steel, P. 1997. Vortex separation technology. Water Quality Research Journal of Canada, 32(1):185-214.

Forstner, U. and Wittmann, G.T.W. 1983. Metal Pollution in the Aquatic Environment, $2^{\text {nd }}$ Edition, Springer-Verlag, New York, $486 \mathrm{p}$.

Gailani, J., Ziegler, C.K., and Lick, W. 1991. Transport of suspended solids in the Lower Fox River. Journal of Great Lakes Research, 17(4):479-494.

Hedges, P.D., Becker, F.A., and Smisson, R.P.M. 1998. The application of settling velocity as a parameter for characterising wastewater solids. Wat. Sci. Tech., 37(1):4552.

Hemond, H.F. and Fechner, E.J. 1994. Chemical Fate and Transport in the Environment, Academic Press, New York, 338 p.

Horsley, S.W. 1997. "StormTreat System Installation at Elm Street, Kingston,

Massachusetts." Journal of Water Management Modeling R195-19. doi:

10.14796/JWMM.R195-19.

Huber, W.C. and Dickinson, R.E. 1988. Storm Water Management Model, Version 4: User's Manual. Distributed by CHI, Guelph, Ontario.

Irvine, K., G.W. Pettibone and I. Droppo. 1995. "Indicator Bacteria-Sediment

Relationships: Implications for Water Quality Modeling and Monitoring." Journal of Water Management Modeling R183-14. doi: 10.14796/JWMM.R183-14.

Irvine, K., I. Droppo, T.P. Murphy and M. Stirrup. 1998. "Annual Loading Estimates of Selected Metals and PAHs in CSOs, using a Continuous PCSWMM Approach." Journal of Water Management Modeling R200-20. doi: 10.14796/JWMM.R200-20.

Klemetson, S.L. 1985. Factors affecting stream transport of combined sewer overflow sediments. Journal Water Pollution Control Federation, 57(5): 390-397.

Kranck, K., Petticrew, E., Milligan, T.G. and Droppo, I.G. 1992. In Situ particle size distributions resulting from flocculation of suspended sediment. In A.J. Mehta (ed.) Nearshore and Estuarine Cohesive Sediment Transport, AGU Volume 42, Washington, pp:60-74.

Kresin, C., W. James and D. Elrick. 1997. "Observations of Infiltration Through Clogged Porous Concrete Block Pavers." Journal of Water Management Modeling R195-10. doi: 10.14796/JWMM.R195-10. 
Lau, Y.L. and Krishnappan, B.G. 1992. Size distribution and settling velocity of cohesive sediments during settling. Journal of Hydraulic Research, 30:673-684.

Lawler, D.F. 1993. Physical aspects of flocculation: From microscale to macroscale. Water Science and Technology, 27(10):165-180.

Lucas-Aiguier, E., Chebbo, G., Bertrand-Krajewski, J.L., Gagne, B., and Hedges, P. 1998. Analysis of the methods for determining the settling characteristics of sewage and stormwater solids. Wat. Sci. Tech., 37(1):53-60.

Marsalek, J., Krishnappan, B.G., Watt, W.E., and Anderson, B.C. 1998. Size distribution of suspended sediments in an on-stream stormwater managementpond. InNOVATECH '98, Proceedings of the $3^{\text {rd }}$ International Conference on Innovative Technologies in Urban Storm Drainage, Lyon, France, Volume 1, pp. 543-550.

McCuen, R.H. 1998. Hydrologic Analysis and Design, $2^{\text {nd }}$ Edition, Prentice Hall, New Jersey, $814 \mathrm{p}$.

Monahan, K.M. 1997. The Effects of Storm Events on Sediment Flocculation in a River Basin. Upubl. M.S. Thesis, SUNY College at Buffalo, $104 \mathrm{p}$.

Nix, S.J., Heaney, J.P., and Huber, W.C. 1988. Suspended solids removal in detention basins. Journal of Environmental Engineering, 114(6):1331-1343.

Ongley, E.D., Krishnappan, B.G., Droppo, I.G., Rao, S.S., and Maguire, R.J. 1992. Cohesive sediment transport: Emerging issues for toxic chemical management. Hydrobiologia, 235/236:177-187.

Palisade Corporation, 1996. BestFit, Probability Distribution Fitting for Windows, User's Guide, Palisade Corporation, Newfield, NY.

Papa, F., B.J. Adams and G.J. Bryant. 1997. "Models for Water Quality Control by Stormwater Ponds." Journal of Water Management Modeling R195-01. doi: 10.14796/JWMM.R195-01.

Paul Theil Associates and Beak Consultants, 1991. Regional Municipality of HamiltonWentworth Pollution Control Plan. Regional Municipality of Hamilton-Wentworth.

Pisano, W.C. and Brombach, H., 1996. Solids settling curves; Wastewater solids data can aid design of runoff controls. Water Environment \& Technology, April:27-33.

Rochefort, Q.J., Anderson, B.C., Crowder, A.A., Marsalek, J., and Watt, W.E. 1997. Field-scale studies of subsurface flow constructed wetlands for stormwater quality enhancement. Water Quality Research Journal of Canada, 32(1):101-117.

Stirrup, M. 1996. Implementation of Hamilton-Wentworth Region's Pollution Control Plan. Water Quality Research Journal of Canada, 31(3):453-472.

Sutherland, R. and S.L. Jelen. 1997. "Contrary to Conventional Wisdom, Street Sweeping Can be an Effective BMP." Journal of Water Management Modeling R195-09. doi: 10.14796/JWMM.R195-09.

Tracy, H., and Craig, G.J. 1993. Ultraviolet (UV) disinfection of stormwater Longfields/ Davidson Heights Stormwater Treatment Facility. In J. Marsalek and H.C. Torno (eds.) Sixth International Conference on Urban Storm Drainage, Niagara Falls, Ontario, Seapoint Publishing, Victoria, B.C. pp. 1133-1138.

Urbonas, B. 1993. Assessment of BMP use and technology today. In J. Marsalek and H.C. Torno (eds.) Sixth International Conference on Urban Storm Drainage, Niagara Falls, Ontario, Seapoint Publishing, Victoria, B.C. pp. 927-932.

Wen, J., Jirka, G.H., and Raggio, G. 1994. Linked sediment/contaminant transport model for rivers with application to the Buffalo River, New York. Journal of Great Lakes Research, 20(4):671-682. 
